\title{
Floating tablets of hydralazine hydrochloride: optimization and evaluation
}

\author{
Kondi Vanithaa, ${ }^{1, *}$, Mohan Varma ${ }^{2}$, Alluri Ramesh ${ }^{1}$ \\ ${ }^{1}$ Vishnu Institute of Pharmaceutical Education and Research,Narsapur, India, ${ }^{2}$ Shri Vishnu College of Pharmacy, Medak, India
}

\begin{abstract}
Hydralazine hydrochloride has a half-life of 2 to 4 hours with an oral bioavailability of 26-50\%. Since hydralazine has a demethylating effect on various suppressor genes, it can be used in various types of cancer to support chemotherapy. The purpose of this study was to optimize and evaluate floating tablets of hydralazine hydrochloride designed to prolong the gastric residence time and to provide controlled release of the drug for $14 \mathrm{~h}$. The floating tablets of hydralazine hydrochloride were prepared by the wet granulation method. Semi-synthetic polymers of hydroxy propyl methyl cellulose (HPMC K100M) and ethyl cellulose were used as the release retarding agents. A $2^{2}$ factorial design was applied to systematically optimize the drug release profile. The concentrations of HPMC K100M and ethyl cellulose were optimized to provide controlled release of hydralazine for $14 \mathrm{~h}$. Non-Fickian diffusion release transport was confirmed as the release mechanism for the optimized formulation and the predicted values agreed well with the experimental values. Drug excipient compatibility studies were investigated by FTIR, DSC and XRD. These data indicate that there were no chemical interactions between the drug and the polymer. In vivo $\mathrm{X}$-ray imaging showed floating tablet performance in rabbits.
\end{abstract}

Uniterms: Hydralazine/floating tablets/evaluation. Hydralazine/floating tablets/optimization. Hydralazine/floating tablets/controlled release. In vivo X-ray/tablets performance. Cancer/treatment.

O cloridrato de hidralazina apresenta meia-vida de 2 a 4 horas, com biodisponibilidade oral de $26-50 \%$. Uma vez que a hidralazina possui efeito desmetilante em vários genes supressores, ela pode ser utilizada para diversos tipos de câncer, em apoio à quimioterapia. O objetivo deste estudo foi o de avaliar e otimizar comprimidos flutuantes de cloridrato de hidralazina, planejados para prolongar o tempo de residência gástrica e proporcionar liberação controlada do fármaco por $14 \mathrm{~h}$. Os comprimidos flutuantes de cloridrato de hidralazina foram preparados pelo método de granulação úmida. Polímeros semi-sintéticos de hidroxipropiletil celulose (HPMCK100M) e acetato de celulose foram utilizados como agente de retardamento de liberação. Aplicou-se planejamento fatorial $2^{2}$ para otimizar sistematicamente o perfil de liberação do fármaco. As concentrações de HPMCK100M e de etilcelulose foram otimizadas para se obter liberação controlada de hidralazina durante 14 h. O transporte de liberação de difusão não-Fickiana foi confirmado como o mecanismo de liberação para a formulação otimizada e os valores previstos estiveram de acordo com os valores experimentais. Estudos de compatibilidade entre fármaco e excipiente foram realizados por FTIR, DSC e DRX. Estes dados indicaram que não havia interação química entre o fármaco e o polímero. Imagens de raios-X in vivo mostraram o desempenho dos comprimidos flutuantes em coelhos.

Unitermos: Hidralazina/comprimidos flutuantes/avaliação. Hidralazina/comprimidos flutuantes/ otimização. Hidralazina/comprimidos flutuantes/liberação controlada. Raios X in vivo/desempenho de comprimidos. Cancer/tratamento.

\section{INTRODUCTION}

Oral drug delivery systems represent an important area of controlled drug delivery, as such dosage forms

*Correspondence: KondiVanitha. Vishnu Institute of Pharmaceutical Education and Research, Narsapur, MEDAK. E-mail: vanithakondi@gmail.com have the major advantage of patient compliance (Dalavi et al., 2010). The overall performance of oral controlled release drug delivery systems is limited by several factors such as physiological variability, gastric retention time, variation in physiological $\mathrm{pH}$ and a narrow absorption window. Gastric retention is useful for those drugs which (i) act locally (Zhenping et al., 2001; Yuveraj, Singh et 
al., 2007); (ii) have a narrow absorption window in the small intestinal region (Streobel et al., 2006); (iii) are unstable in the intestinal environment and (iv) have poor solubility in a high $\mathrm{pH}$ environment. Various dosage forms have been developed for gastric retention; these include floating tablets (Sathis et al., 2011) floating beads, pellets, floating granules and floating microspheres. Hydralazine is a directly acting smooth muscle relaxant used to treat hypertension by acting as a vasodilator. It is the first-line therapy for hypertension in pregnancy along with methyldopa. The drug is insoluble in water and has a half-life of 2 to 4 hours with an oral bioavailability of $26-50 \%$. In the recent years, more attention has been directed towards hydralazine, since it has a demethylating effect on various suppressor genes. Therefore, it can be used in various types of cancer to support chemotherapy (Melike, Benek, 2012; Song et al., 2009).In the present study, an attempt was made to optimize (Singh et al., 2009 ) the concentration of semi-synthetic polymers for the controlled release of hydralazine and to minimize its side effects by administration of a lower dose. As hydralazine can also be used as a support in cancer therapy, the controlled release formulation was prepared using various polymers. Sodium bicarbonate was used as a gas generating agent. Drug-excipient compatibility was studied by Fourier transform infrared spectroscopy (FT-IR), differential scanning calorimetry (DSC) and X-ray diffraction(XRD). An in vivo X-ray imaging study was performed to show floating tablet performance in rabbits.

\section{MATERIAL AND METHODS}

Hydralazine was donated by Hetero Drugs Ltd., Hyderabad, India. HPMC K100M and ethyl cellulose were obtained as gift samples from Matrix Labs, Hyderabad. Other ingredients used were of analytical grade.

\section{Optimization of formulation}

The optimization technique encompassed designing a set of experiments that could reliably measure the response variables, fitting a mathematical model to the data, conducting appropriate statistical tests to assure that the best possible model was chosen, and determining the values of the independent formulation variables to produce the optimum response (Gupta et al., 2008).

\section{Experimental design}

In the preliminary studies, eight formulations with different drug/polymer ratios were formulated based on a $2^{2}$ factorial design (Madan et al., 2009). The design included two factors each evaluated at two levels. The proportion of the retardant materials HPMC K100M $\left(\mathrm{X}_{1}\right)$ and ethyl cellulose $\left(\mathrm{X}_{2}\right)$ were selected as the independent variables. Drug release at $1.5\left(\mathrm{Y}_{1}\right), 4\left(\mathrm{Y}_{2}\right), 8\left(\mathrm{Y}_{3}\right)$ and 14 hours $\left(\mathrm{Y}_{4}\right)$ was selected as the dependent variable in this study. The plan of the experiment is given in Table I.

TABLE I - Plan of the experiments with coded levels of the variables

\begin{tabular}{lccc}
\hline Sl. No. & Variables & $\mathrm{X}_{1}$ & $\mathrm{X}_{2}$ \\
\hline 1 & $\mathrm{X}_{0}$ & -1 & -1 \\
2 & $\mathrm{X}_{1}$ (HPMC K100M) & 1 & -1 \\
3 & $\mathrm{X}_{2}$ (Ethyl cellulose) & -1 & 1 \\
4 & $\mathrm{X}_{1} \mathrm{X}_{2}$ (Interaction) & 1 & 1 \\
5 & Midpoint & & \\
6 & Midpoint & & \\
7 & Midpoint & & \\
8 & Midpoint & & \\
\hline
\end{tabular}

\section{Preparation of tablets}

The formulations were prepared by the wet granulation method (Garget al., 2009) at random following a $2^{2}$ factorial design. The various excipients used are listed in Table II. All the ingredients, expect magnesium stearate and talc, were thoroughly mixed and passed through a no. 60 sieve. Granulation was performed with a solution of $0.5 \%$ PVPK 30 in ethyl alcohol. The wet mass was passed through a no. 40 sieve and dried at $50{ }^{\circ} \mathrm{C}$ for $10 \mathrm{~min}$. The dried granules were lubricated with magnesium stearate and talc and compressed into tablets using a Cadmach 21 station rotary tablet compression machine.

\section{In vitro buoyancy studies}

The tablets were placed in a $100 \mathrm{~mL}$ beaker containing $0.1 \mathrm{~N} \mathrm{HCl}$ at a temperature of $37 \pm 0.5^{\circ} \mathrm{C}$. The time taken for the tablet to rise to the surface is called the floating lag time. The total period of time the dosage form remains on the surface of the media is called the total floating time.

\section{Dissolution studies}

In vitro dissolution study of hydralazine was performed using a USP Type I basket dissolution apparatus in $900 \mathrm{~mL}$ of $0.1 \mathrm{NHCl}$ at $37^{\circ} \mathrm{C}(50 \mathrm{rpm})$ (Sameer,Singh et al., 2011). Samples were withdrawn, filtered, suitably diluted and assayed at $302 \mathrm{~nm}$ on a UV spectrophotometer. The samples were then replaced with fresh dissolution medium. 
TABLE II - Formulation of floating tablets of hydralazine

\begin{tabular}{lcccccccc}
\hline Ingredients & $\mathrm{F} 1$ & $\mathrm{~F} 2$ & $\mathrm{~F} 3$ & $\mathrm{~F} 4$ & $\mathrm{~F} 5$ & $\mathrm{~F} 6$ & $\mathrm{~F} 7$ & $\mathrm{~F} 8$ \\
\hline Hydralazine & 50 & 50 & 50 & 50 & 50 & 50 & 50 & 50 \\
HPMCK100M & 100 & 150 & 100 & 150 & 125 & 125 & 125 & 125 \\
Ethyl cellulose & 20 & 20 & 40 & 40 & 30 & 30 & 30 & 30 \\
NaHCO $_{3}$ & 45 & 45 & 45 & 45 & 45 & 45 & 45 & 45 \\
Mgstearate & 6 & 6 & 6 & 6 & 6 & 6 & 6 & 6 \\
Talc & 6 & 6 & 6 & 6 & 6 & 6 & 6 & 6 \\
Lactose & 58 & 8 & 38 & 3 & 38 & 38 & 38 & 38 \\
\hline Total wt. & 300 & 300 & 300 & 300 & 300 & 300 & 300 & 300 \\
\hline All & & & & & & & &
\end{tabular}

All values are in given in $\mathrm{mg}$

Kinetic modeling of drug release

The dissolution profile of all the batches was fitted to zero order, first order, Higuchi, Korsemeyer and Peppas models to ascertain the kinetic modeling of drug release (Dave et al., 2004).

\section{Drug-polymer compatibility}

\section{FT-IR analysis}

FT-IR was carried out to assess the interaction between the drug and the tablet excipients. For this, sufficient amounts of the pure drug and powdered hydralazine tablets were scanned over a wavenumber range of 4000 to $650 \mathrm{~cm}^{-1}$ at a resolution of $4 \mathrm{~cm}^{-1}$ on a BRUKER Alpha FT-IR spectrometer (serial number:200218). The system was operated in transmission mode.

\section{DSC analysis}

Thermal analysis were carried out using a differential scanning calorimeter (Perkin Elmer DSC Pyris-1, Perkin Elmer Inc.).
XRD studies

Diffractograms of the drug, HPMC and floating tablets were obtained using a Philips PW 1830 X-ray diffractometer.

In vivo radio imaging study

The optimized floating tablets excluding the drug and containing barium sulfate (50 $\mathrm{mg}$ per tablet) were prepared and studied for in vivo X-ray imaging study to establish the product performance in rabbits

\section{RESULTS AND DISCUSSION}

The floating tablets containing hydralazine hydrochloride were prepared by the wet granulation method at random following a $2^{2}$ factorial design. According to this trial proposal, eight experimental formulations of floating tablets containing hydralazine hydrochloride were prepared. An overview of the experimental plan and observed response values are presented in Table III. The Design-Expert 7.1.6 software

TABLE III - Experimental plan and observed response values from randomized runs in a $2^{2}$ factorial design for the development of floating tablets containing hydralazine hydrochloride

\begin{tabular}{lccccccc}
\hline \multirow{2}{*}{ Std } & Run & Factor1 & Factor 2 & Response 1 & Response 2 & Response 3 & Response 4 \\
\cline { 2 - 7 } & & HPMC K100 $\left(\mathrm{X}_{1}\right)$ & $\mathrm{EC}\left(\mathrm{X}_{2}\right)$ & Dissolution $1.5 \mathrm{~h}$ & Dissolution 4h & Dissolution $8 \mathrm{~h}$ & Dissolution 14 h \\
\hline 8 & 1 & 125 & 30 & 17 & 49 & 70 & 92 \\
6 & 2 & 125 & 30 & 20 & 52 & 71 & 94 \\
5 & 3 & 125 & 30 & 19 & 49 & 69 & 92 \\
7 & 4 & 125 & 30 & 17 & 50 & 72 & 95 \\
2 & 5 & 150 & 20 & 8 & 49 & 68 & 92 \\
4 & 6 & 150 & 40 & 27 & 46 & 63 & 87 \\
3 & 7 & 100 & 40 & 25 & 52 & 75 & 98 \\
1 & 8 & 100 & 20 & 28 & 61 & 72 & 97 \\
\hline
\end{tabular}


provided suitable model equations involving the individual main factors and interaction factors for each investigated response after fitting these data. These models were evaluated statistically by applying one-way ANOVA. All these models were found to be significant $(p<0.05)$.

The model equations in terms actual factors generated by the Design-Expert 7.1.6 software are given below:

Dissolution after $1.5 \mathrm{~h}=115.00-0.84 \mathrm{X}_{1}-2.35 \mathrm{X}_{2}+$ $0.022 \mathrm{X}_{1} \mathrm{X}_{2}\left[\mathrm{R}^{2}=0.0 .9181 ; p=0.0388\right]$;

Dissolution after $4 \mathrm{~h}=83.50-0.18 \mathrm{X}_{1}-0.30 \mathrm{X}_{2}$ $\left[\mathrm{R}^{2}=0.8954 ; p=0.0338\right]$;

Dissolution after $8 \mathrm{~h}=61.00+0.08 \mathrm{X}_{1}+0.95 \mathrm{X}_{2}-0.008$ $\mathrm{X}_{1} \mathrm{X}_{2}\left[\mathrm{R}^{2}=0.9204 ; p=0.0372\right]$; and

Dissolution after $14 \mathrm{~h}=94.00+0.02 \mathrm{X}_{1}+0.65 \mathrm{X}_{2}$ $0.006 \mathrm{X}_{1} \mathrm{X}_{2}\left[\mathrm{R}^{2}=0.9420 ; p=0.0231\right]$

The main effects of factors $\mathrm{X}_{1}$ and $\mathrm{X}_{2}$ were larger compared to the effects of their interaction, i.e. $X_{1} X_{2}$. The curvature effect was insignificant and the steepest ascent method was chosen for optimization. $\mathrm{X}_{1}$ was the major factor; an increased polymer concentration reduced drug release, while ethyl cellulose had a negligible effect on drug release. Ethyl cellulose and HPMC K100M interaction was insignificant.

The limit for the estimated response for the preparation of optimized floating tablets of hydralazine hydrochloride was considered to be for $1.5 \mathrm{~h}$ : NMT $25 \%$; 4 h: $50-60 \%$; 8 h: $60-70$; and 14 h: NLT $80 \%$. The overlay plot indicating the region of optimal process variable settings is presented in Figure 1.

\section{ANOVA study}

The coefficients of $X_{1}$ were found to be significant at $p<0.05$, confirming the significant effect on the selected responses. Increasing the concentration of HPMC K100M resulted in a decrease in the release of hydralazine. This was found to be close to unity, indicating good estimation of the coefficient. Similarly, Ri-squared was close to zero, which led to a good model. The values of Prob $>$ F were less than 0.05 , which indicated that the model terms were significant. In all cases, "Pred R-squared" values were in reasonable agreement with the "Adj R-squared" values. Adeq-Precision is a measure of the signal to noise ratio; a ratio $>4$ is desirable. In this case, the Adeq-Precision values were $9.41,9.29,10.39$ and 11.60 for $1.5 \mathrm{~h}, 4 \mathrm{~h}, 8 \mathrm{~h}$ and $14 \mathrm{~h}$, respectively, which indicated an adequate signal. However, both the variables favored the preparation of controlled release floating tablets of hydralazine. The statistical approach for formulation (optimization) is a useful tool, particularly when simultaneously evaluating several variables. The observed responses were in close agreement with the predicted values of the optimized formulations, demonstrating the feasibility of the optimization procedure for developing floating tablets of hydralazine hydrochloride.

According to the overlay plot (Figure 1), the optimum concentrations are $130 \mathrm{mg}$ for $\mathrm{X}_{1}$ and $30 \mathrm{mg}$ for $\mathrm{X}_{2}$.

\section{In vitro buoyancy}

All floating tablets of hydralazine hydrochloride floated well over a long period of time (not less than

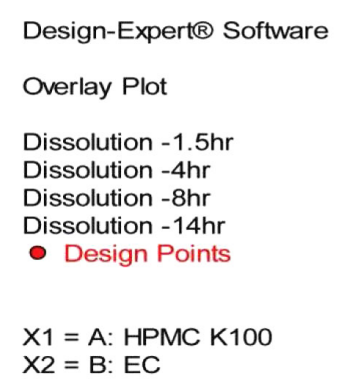

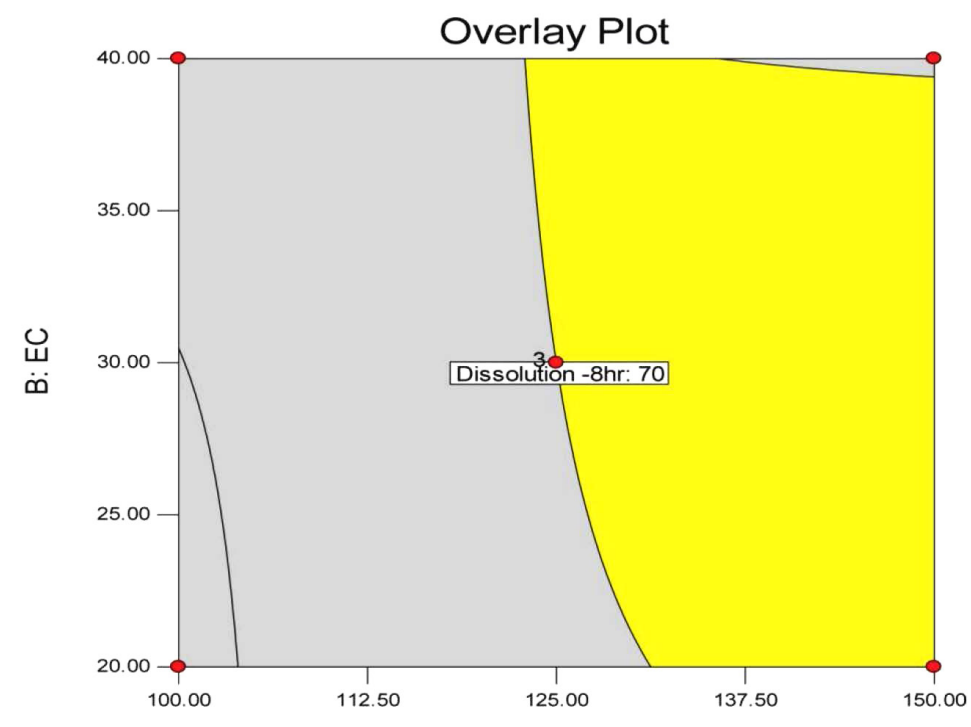

A: HPMC K100

FIGURE 1 - Overlay plot indicating the region of optimal process variable settings in the development of floating tablets of hydralazine hydrochloride. 
TABLE IV - Evaluation of the physicochemical parameters of hydralazine hydrochloride

\begin{tabular}{lccccccc}
\hline $\begin{array}{l}\text { Formulation } \\
\text { code }\end{array}$ & $\begin{array}{c}\text { Weight }(\mathrm{mg}) \\
\mathrm{n}=20\end{array}$ & $\begin{array}{c}\text { Hardness } \pm \mathrm{SD} \\
\left(\mathrm{kg} / \mathrm{cm}^{2}\right) \\
\mathrm{n}=10\end{array}$ & $\begin{array}{c}\text { Drug } \\
\text { content } \% \pm \mathrm{SD} \\
(\mathrm{n}=3)\end{array}$ & $\begin{array}{c}\text { Friability } \\
(\%)\end{array}$ & $\begin{array}{c}\text { Thickness } \\
(\mathrm{mm})\end{array}$ & $\begin{array}{c}\text { Floating lag } \\
\text { time }\end{array}$ & $\begin{array}{c}\text { Floating } \\
\text { duration (h) } \\
\mathrm{n}=3\end{array}$ \\
\hline F1 & $300.54 \pm 1.28$ & $5.63 \pm 0.42$ & $98.25 \pm 3.01$ & 0.13 & $3.45 \pm 0.05$ & $16 \mathrm{sec}$ & $24 \pm 1.00$ \\
F2 & $300.05 \pm 1.12$ & $5.85 \pm 0.65$ & $102.03 \pm 2.4$ & 0.12 & $2.97 \pm 0.02$ & $12 \mathrm{sec}$ & $24 \pm 0.05$ \\
F3 & $300.15 \pm 1.10$ & $6.91 \pm 0.34$ & $99.70 \pm 3.51$ & 0.14 & $3.71 \pm 0.09$ & $20 \mathrm{sec}$ & $24 \pm 1.05$ \\
F4 & $299.59 \pm 1.29$ & $6.58 \pm 0.49$ & $100.81 \pm 0.7$ & 0.13 & $3.51 \pm 0.10$ & $16 \mathrm{sec}$ & $24 \pm 0.07$ \\
F5 & $300.00 \pm 0.92$ & $6.11 \pm 0.36$ & $97.23 \pm 0.25$ & 0.16 & $3.13 \pm 0.03$ & $18 \mathrm{sec}$ & $24 \pm 0.05$ \\
F6 & $299.91 \pm 1.33$ & $6.45 \pm 0.53$ & $99.17 \pm 0.42$ & 0.12 & $3.15 \pm 0.07$ & $30 \mathrm{sec}$ & $24 \pm 1.00$ \\
F7 & $299.61 \pm 1.47$ & $6.63 \pm 0.54$ & $101.47 \pm 2.8$ & 0.13 & $3.45 \pm 0.11$ & $25 \mathrm{sec}$ & $24 \pm 0.06$ \\
F8 & $299.35 \pm 1.37$ & $6.63 \pm 0.43$ & $100.01 \pm 3.0$ & 0.15 & $3.35 \pm 0.08$ & $20 \mathrm{sec}$ & $24 \pm 0.04$ \\
Optimized & $299.57 \pm 1.30$ & $6.92 \pm 0.33$ & $98.45 \pm 3.5$ & 0.12 & $3.87 \pm 0.08$ & $15 \mathrm{sec}$ & $24 \pm 0.08$ \\
formulation & & & & & & & \\
\hline
\end{tabular}

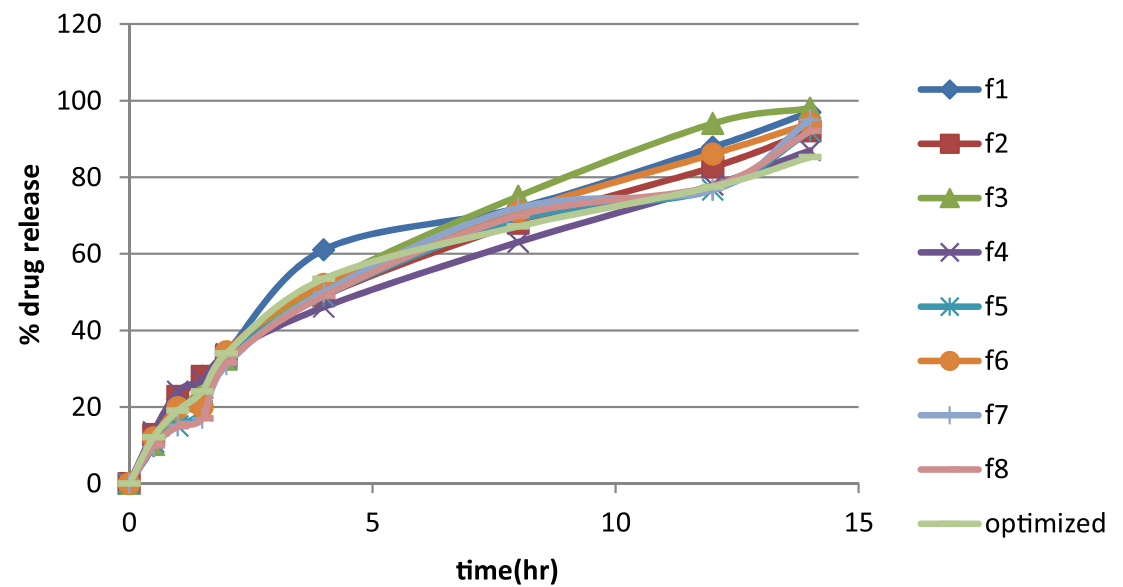

FIGURE 2 - In vitro hydralazine hydrochloride release from hydralazine hydrochloride floating tablets in $0.1 \mathrm{~N} \mathrm{HCl}$.

24 hours) with no minimum floating lag time (12 to 30 seconds) (Table IV). These floating tablets contained sodium bicarbonate as an effervescent agent. An effervescent agent generally produces $\mathrm{CO}_{2}$, which reduces the density of the system and makes it float on an aqueous medium.

\section{In vitro dissolution}

In vitro hydralazine hydrochloride release from various hydralazine hydrochloride floating tablets in $0.1 \mathrm{~N} \mathrm{HCl}$ is presented in Figure 2. The drug release was found to be sustained over a prolonged period of time $(14 \mathrm{~h})$. In these floating tablets, HPMC K100M and ethylcellulose were used as release retardant materials. The greater viscosity due to HPMC K100M may promote the formation of a highly viscous gel upon contact with aqueous fluids. This would retard the drug release rate from these floating tablets. A comparison of the percentage of drug release using the Experimented (E) and Predicted (P) values for the most probable optimal formulation are given in Table $\mathrm{V}$.

\section{Analysis of drug release data}

The drug release kinetics was evaluated using the linear regression method (Table VI). The best fit with

TABLE V - Comparison of percentage ofdrug release between the experimented (E) and predicted $(\mathrm{P})$ values for the most probable optimal formulation

\begin{tabular}{lcc}
\hline Time interval & Predicted value & Experimental value \\
\hline $1.5 \mathrm{~h}$ & NMT $25 \%$ & 24.05 \\
$4 \mathrm{~h}$ & $50-60 \%$ & 53.49 \\
$8 \mathrm{~h}$ & $60-70 \%$ & 67.17 \\
$14 \mathrm{~h}$ & NLT $80 \%$ & 85.26 \\
\hline
\end{tabular}


TABLE VI - Drug release kinetics of floating tablets of hydralazine hydrochloride

\begin{tabular}{lccccc}
\hline \multirow{2}{*}{ Formulation code } & Zero order & First order & Higuchi kinetics & \multicolumn{2}{c}{ Koresmeyer-Peppas equation } \\
\cline { 4 - 6 } & $\mathrm{R}^{2}$ & $\mathrm{R}^{2}$ & $\mathrm{R}^{2}$ & $\mathrm{n}$ & $\mathrm{R}^{2}$ \\
\hline F1 & 0.881 & 0.971 & 0.981 & 0.494 & 0.986 \\
F2 & 0.911 & 0.947 & 0.995 & 0.489 & 0.996 \\
F3 & 0.846 & 0.972 & 0.954 & 0.550 & 0.948 \\
F4 & 0.914 & 0.896 & 0.996 & 0.461 & 0.999 \\
F5 & 0.899 & 0.924 & 0.990 & 0.513 & 0.982 \\
F6 & 0.864 & 0.964 & 0.976 & 0.516 & 0.972 \\
F7 & 0.907 & 0.904 & 0.992 & 0.536 & 0.983 \\
F8 & 0.905 & 0.913 & 0.991 & 0.533 & 0.983 \\
Optimized & 0.931 & 0.975 & 0.995 & 0.480 & 0.991 \\
formulation & & & & \\
\hline
\end{tabular}

the highest coefficients of determination $\left(\mathrm{R}^{2}\right)$ was shown by both the Higuchi and first order models followed by zero order, which indicates that drug release followed the diffusion mechanism. The results of the in vitro release data were fitted to the Korsemeyer-Peppas equation to analyze the release pattern of the drug from the polymeric system. The values of " $n$ " were in the range of $0.48-0.55$, indicating that drug release followed Fickian diffusion.
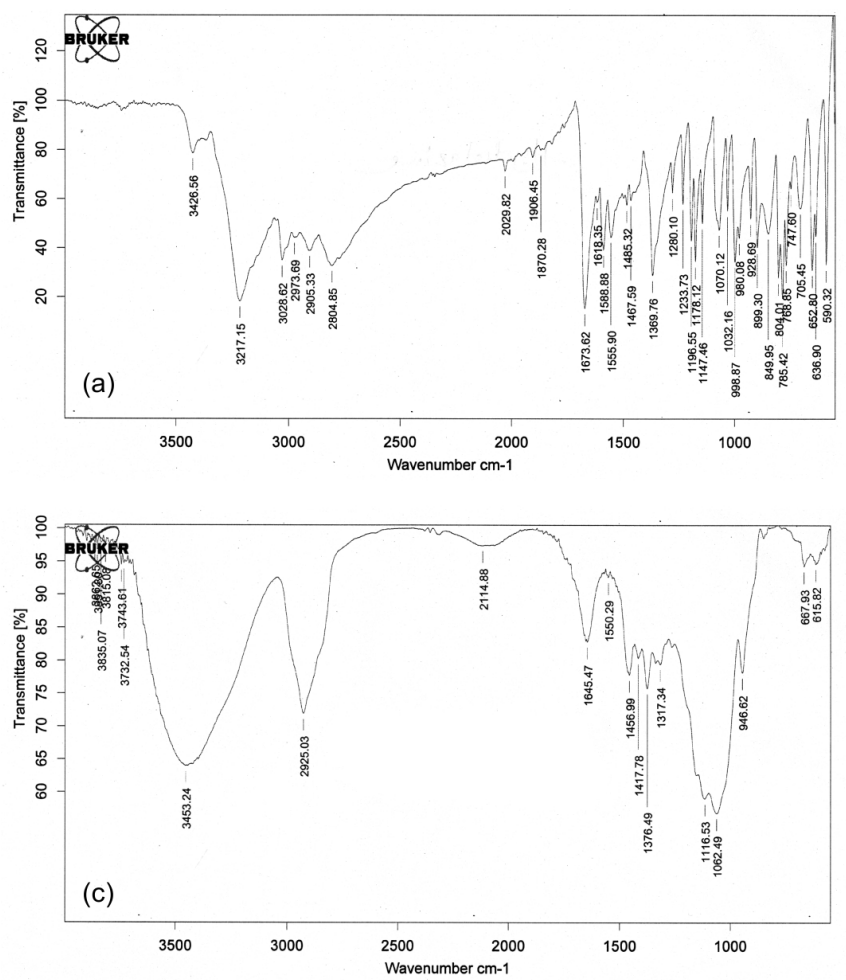

\section{Drug-polymer compatibility}

\section{FT-IR analysis}

The FT-IR spectra of pure hydralazine hydrochloride, the optimized formulation, HPMC K100M and ethyl cellulose are presented in Figure 3. The characteristic peaks were at $3218.41 \mathrm{~cm}^{-1}(\mathrm{~N}-\mathrm{H}$ stretching), $3028.47 \mathrm{~cm}^{-1}$ (aromatic C-H stretching), $2974 \mathrm{~cm}^{-1}$
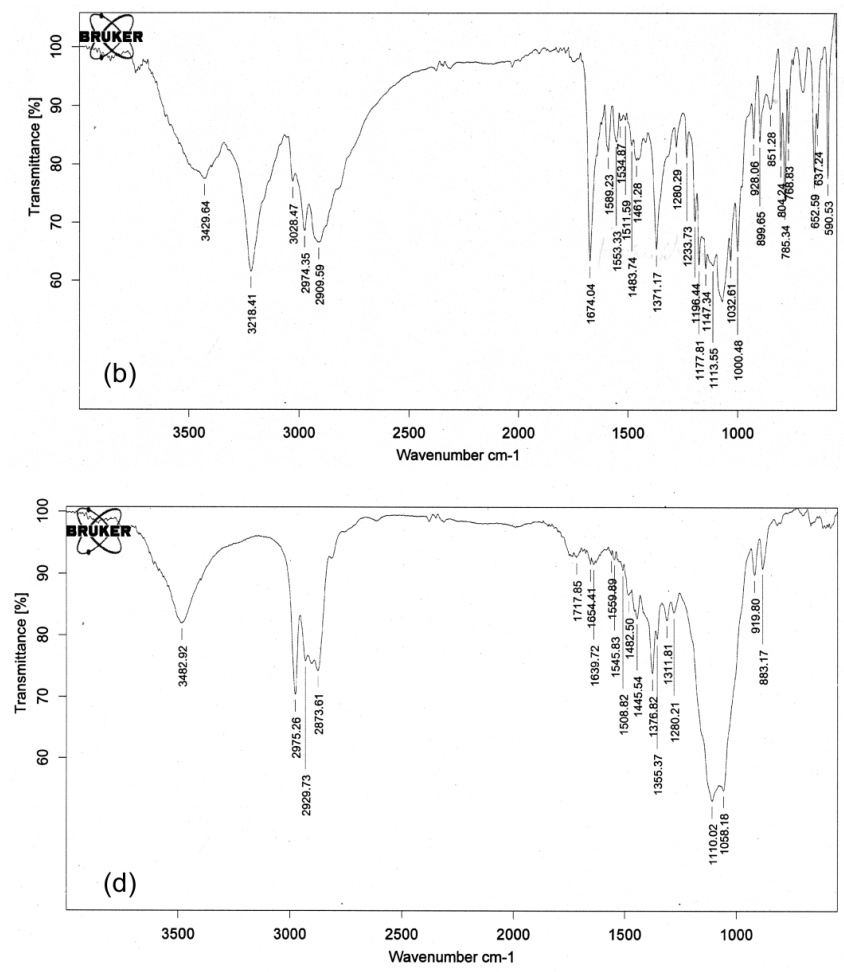

FIGURE 3 - FTIR spectra of a. Pure drug b. Optimized formulation C.HPMC K100M d.Ethyl cellulose. 
(CH stretching due to methyl groups), 2904-1674 $\mathrm{cm}^{-1}$ (aromatic C-H vibrations), $2804 \mathrm{~cm}^{-1}$ (C-H stretching), $2029-1870 \mathrm{~cm}^{-1}(\mathrm{C}=\mathrm{C}$ stretching $)$ and $1673-1467 \mathrm{~cm}^{-1}(\mathrm{C}-\mathrm{C}$ stretching due to the aromatic ring). In the optimized formulation, the main bands of hydralazine were detected at a lower intensity due to the polymers. The characteristic peaks present in the FT-IR spectrum of both HPMC $\mathrm{K} 100 \mathrm{M}$ and ethylcellulose also appeared in the spectra of floating tablets of hydralazine hydrochloride. These phenomena indicate that there was an absence of any chemical interaction between the drug and the excipients.

\section{DSC analysis}

DSC thermograms of pure hydralazine hydrochloride, the optimized formulation, HPMC K100M and ethyl cellulose are presented in Figure 4. The DSC of pure hydralazine hydrochloride showed an endothermic peak at $282.5^{\circ} \mathrm{C}$, indicating the melting point of drug. In the DSC of HPMC K100M, broad endotherm at $83.9^{\circ} \mathrm{C}$ was observed, which may have been due to evaporation of absorbed water, as well as a broad endotherm at $352.8^{\circ} \mathrm{C}$ indicated the absence of a sharp melting point. In ethyl cellulose, a broad endotherm at $332.8^{\circ} \mathrm{C}$ indicated the absence of a sharp melting point. The characteristic peaks that appeared in pure hydralazine hydrochloride were present in the optimized formulation and were absent
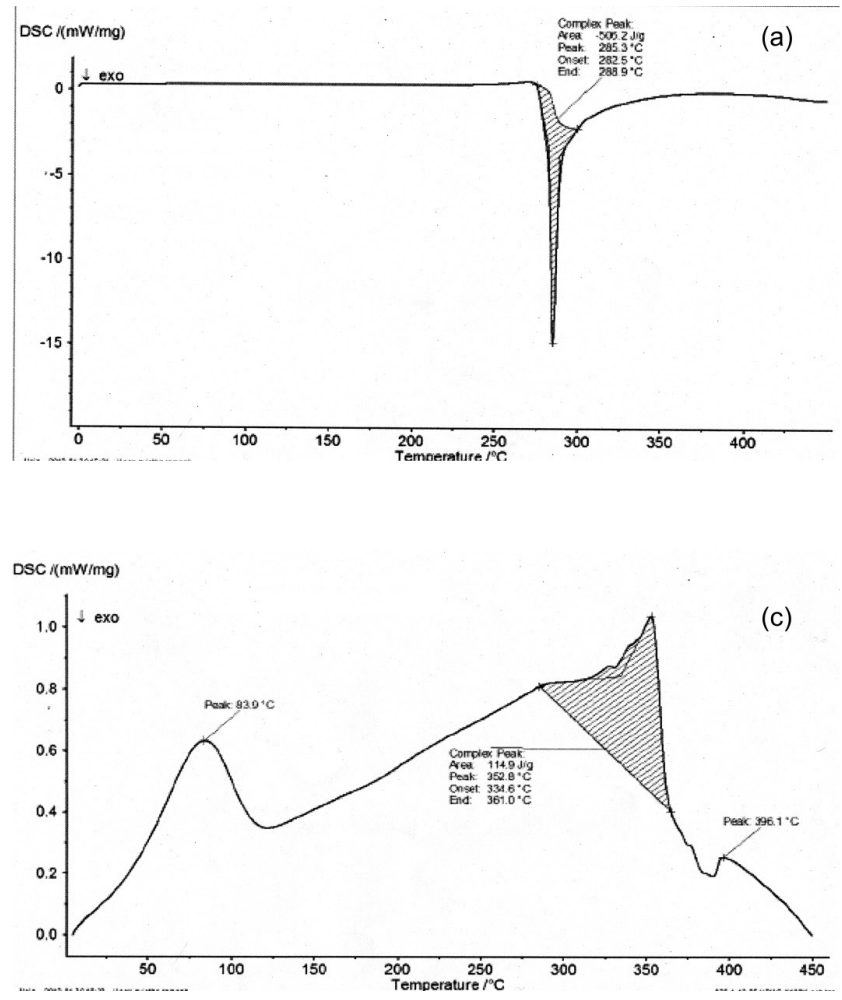

in the DSC thermograms of both HPMC K100M and ethylcellulose. These results indicate the absence of any chemical interactions between the drug and the excipients used in the formulation.

\section{XRD analysis}

The XRD pattern of pure hydralazine hydrochloride, the optimized formulation, HPMC K100M and ethyl cellulose are presented in Figure 5. The XRD pattern of hydralazine hydrochloride indicated crystalline characteristics, which was similar to the pattern of the optimized floating tablets of hydralazine hydrochloride; the polymer diffractograms showed an amorphous pattern.

\section{In vivo radio imaging study}

The optimized floating tablets excluding the drug and containing barium sulfate (50 mg per tablet) were prepared and studied in an in vivo X-ray imaging study to establish product performance in rabbits. An X-ray image is shown in Figure 6. X-ray images were taken at 0.5, 2 and $6 \mathrm{~h}$. The presence of the floating tablet in the upper gastrointestinal tract was clearly observed in these X-ray images. The in vivo $\mathrm{X}$-ray imaging study clearly indicated that the prepared optimized floating tablet was retained in the rabbit stomach over a prolonged period of time and had good in vivo performance. Ethical clearance for
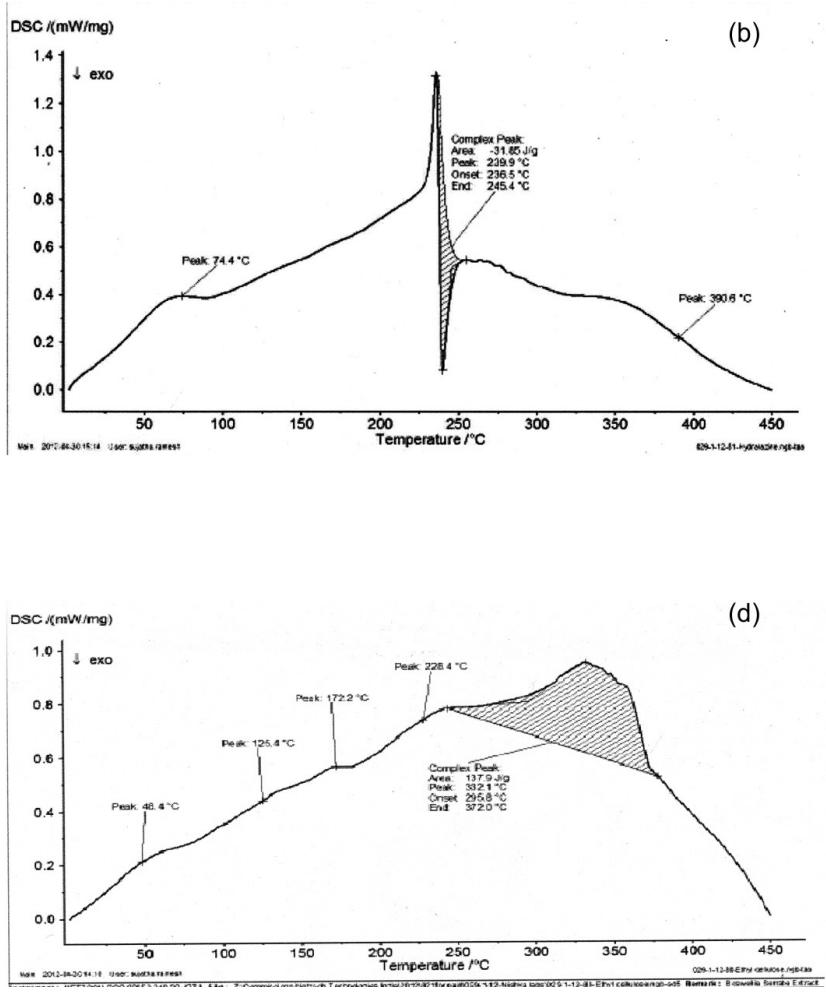

FIGURE 4 - DSC thermograms of the pure drug (a), the optimized formulation (b), HPMC K 100M (c) and ethyl cellulose (d). 

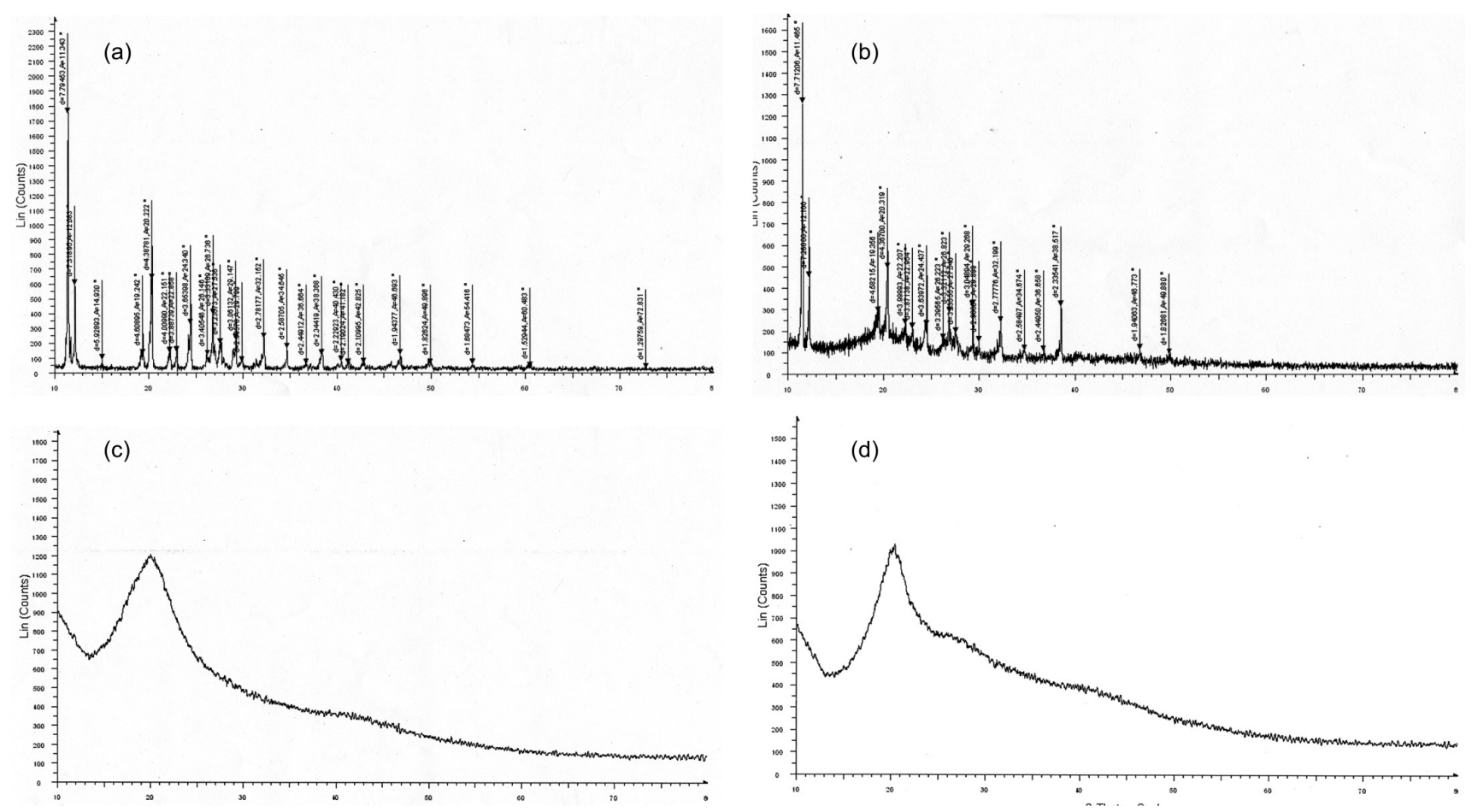

FIGURE 5 - XRD pattern of the pure drug (a), the optimized formulation (b), HPMC K100M (c) and ethyl cellulose (d).

the handling of experimental animals was obtained from the Vishnu institutional animal ethical committee (IAEC No.1358/ac/10/cpcsea) constituted for this purpose.

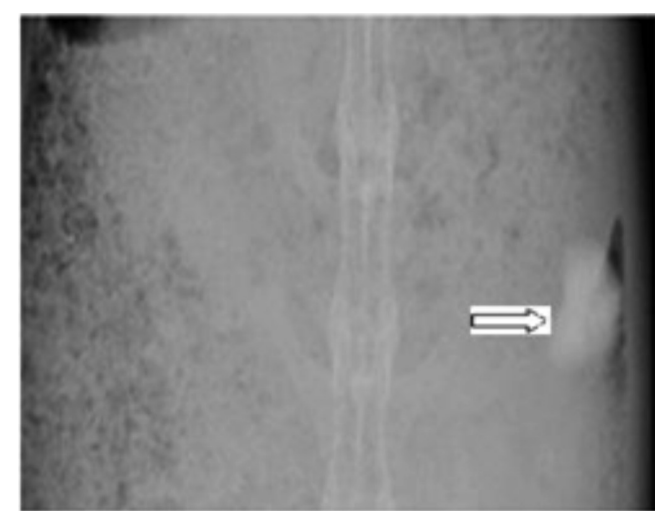

FIGURE 6 - X ray photograph of the optimized formulation in a rabbit after $6 \mathrm{~h}$.

\section{CONCLUSION}

A floating drug delivery system is a promising approach to achieve in vitro buoyancy and extended drug release using the synthetic polymer HPMCK100M, ethyl cellulose and gas generating agent sodium bicarbonate. A systematic study using a $2^{2}$ factorial design revealed that, by selecting a suitable composition of HPMCK $100 \mathrm{M}$ and ethyl cellulose, the desired dissolution profile could be achieved. The regression coefficient $\left(\mathrm{R}^{2}\right)$ values of the release data of all the formulations were obtained by the curve fitting method for the zero order, first order, Higuchi and the Korsemeyer-Peppas models. Most of the formulations followed the Korsemeyer and Higuchi models. The $\mathrm{R}^{2}$ value of the optimized formulation was 0.991 and the $\mathrm{n}$ value was 0.48 , indicating Fickian release governed by drug diffusion and the absence of an interaction between the drug and the polymer. An in vivo $\mathrm{X}$-ray imaging study clearly indicated that the prepared optimized floating tablet was retained in the rabbit stomach over a prolonged period of time and showed good in vivo performance.

\section{ACKNOWLEDGMENTS}

We acknowledge with thanks Prof. C.V.S. Subramanyam, Professor \& Principal, Gokaraju Rangaraju college of pharmacy, Hyderabad for providing support in Optimization techniques and the software.

\section{REFERENCES}

DALAVI, V.V.; PATIL, J.S. Statistical optimization and development of gastro retentive system of an antiretroviral drug using a $3^{2}$ factorial design. Indian J. Pharm. Educ. Res., v.44, p.236-242, 2012. 
DAVE, B.S.; AMIN, A.F.; PATEL, M.M. Gastroretentive drug delivery system of ranitidine hydrochloride:formulation and In Vitro evaluation. AAPS Pharmscitech., v.5, p.7782, 2004.

GARG, R.; GUPTA, G.D. Preparation and evaluation of gastrorententive floating tablets of Silymarin. Chem. Pharm. Bull, v.57, p.545-549,2009.

GUPTA, R.; PATHAK, K. Optimization studies on floating multiparticulate gastroretentive drug delivery system of famotidine. Drug Dev. Ind. Pharm., v.34, p.1201-1208, 2008.

MADAN MOHAN, K.; NITA, M.; LAKSHMI KANTA, G.; BIJAN KUMAR, G. Multiunit floating drug delivery of rosiglitazone maleate: development, characterization, statistical optimization of drug release and InVivo evaluation. AAPS Pharmscitech., v.10, p.887-899, 2009.

MELIKE, U.; BENEK, C. Design of hydralazine hydrochloride matrix tablets based on various polymers and lipids. Indian J. Pharm. Educ. Res., v.46, p.75-87, 2012.

SAMEER, S.; KALPANA, P.; PATHAK, A.K.; MISHRA, A. Formulation and evaluation of floating tablet of captopril. Int. J. Pharm. Technol. Res.,v.13, p.333-341, 2011.

SATHIS KUMAR, D.; SANTHOS, K.; DAVID, B.; HARANI, A.; VENKATESHWAR, R. Formulation and evaluation of bi-layer floating tablets of ziprasidone $\mathrm{HCl}$ and trihexyphenidyl HCl. Braz. J. Pharm. Sci., v.47, p.545553, 2011.
SINGH, B.; PAHUJA, S.; KAPIL, R.; AHUJA, N. Formulation development of oral controlled release tablets of hydralazine: optimization of drug release and bioadhesive characteristics. Acta Pharm., v.59, p.1-13, 2009.

SONG, Y.; ZHANG, C. Hydralazine inhibits human cervical cancer cell growth in vitro in association with APC demethylation and re-expression. Cancer Chemother. Pharmacol., v.63, p.605-613, 2009.

STREOBEL, A.; SIEPMANN, J.; BODMEIER., R. Gastroretentive drug delivery systems. Expert. Opin. Drug Del., v.3, p.217-233, 2006.

YUVERAJ SINGH, T.; PUSHPENDRA SINGH, N.; GARIMA RANI, O. Development and evaluation of floating microspheres of verapamil hydrochloride. Braz. J. Pharm. Sci.,v.43, p.529-534, 2007.

ZHENPING, W.; ZHANFENG,Y.; DIANZHOU,B. Design and evaluation of a two layer floating tablet for gastric retention using cisalpine as a model drug. Drug Dev. Ind. Pharm., v.27, p.469-474, 2001.

Received for publication on 14 December 2012 Accepted for publication on 04 June 2013 